\title{
Growth of interstitial ciliates in association with ciliate bacterivory in a sandy hyporheic zone
}

\author{
Ernst-Josef Cleven ${ }^{1,2, *}$, Sascha Königs ${ }^{1}$ \\ ${ }^{1}$ Department of General Ecology and Limnology, Zoological Institute, University of Cologne, Weyertal 119, 50923 Köln, \\ Germany \\ ${ }^{2}$ Present address: Institute for Evolution and Biodiversity, University of Münster, Hüfferstraße 1, 48149 Münster, Germany
}

\begin{abstract}
In situ growth rates of interstitial ciliates of a sandy hyporheic zone were determined by a modification of the dilution technique. Preconditioned sediment was used as a dilution substrate. Field incubation was conducted in the upper $3 \mathrm{~cm}$ sediment layer; samples were taken on 3 days (Days 0, 21 and 35) in October to November 2002. Mean growth rates varied between $0.070 \mathrm{~d}^{-1}\left(\mathrm{Pleu}^{-}\right.$ ronema spp.) and $0.089 \mathrm{~d}^{-1}$ (other small scuticociliates) for the $21 \mathrm{~d}$ incubation period and between $0.093 \mathrm{~d}^{-1}$ (Hymenostomatia) and $0.145 \mathrm{~d}^{-1}$ (Placus spp.) for the $35 \mathrm{~d}$ incubation period. Mean generation times ranged between 4.8 and $9.9 \mathrm{~d}$. Ciliate carbon production, determined on the basis of significant growth and mortality rates and summed up for the respective incubation period, ranged between $7 \mathrm{ng} \mathrm{C} \mathrm{g}^{-1}$ sediment dry weight (DW) (Cinetochilum margaritaceum) and $226 \mathrm{ng} \mathrm{C} \mathrm{g}^{-1} \mathrm{sedi}^{-}$ ment DW (Hymenostomatia) for the $21 \mathrm{~d}$ incubation period, and was $6 \mathrm{ng} \mathrm{C} \mathrm{g}^{-1}$ sediment DW for the 35 d incubation period (Placus spp. ). Losses due to predation ranged from 13.3 to $17.9 \% \mathrm{~d}^{-1}$ for ciliate carbon biomass and from 114.9 to $250.1 \% \mathrm{~d}^{-1}$ for ciliate carbon production. Fluorescence in situ hybridisation (FISH) was used to determine taxon-specific bacteria ingestion. Ingestion rates for $C$. margaritaceum, other small scuticociliates and Pleuronema spp. were 26, 50 and 86 bacteria ind. $^{-1}$ $\mathrm{h}^{-1}$, respectively. Based on the estimated gross growth rates and on ciliate biomass and bacteria ingestion, we calculated the carbon requirement and the bacteria carbon ingestion required to enable this growth. The mean contribution of bacterivory to the carbon requirement for $C$. margaritaceum, other small scuticociliates and Pleuronema spp. amounted to only $7.0,11.8$ and $2.2 \%$, respectively.
\end{abstract}

KEY WORDS: Hyporheic zone - Ciliates - Growth - Biomass · Fluorescence in situ hybridisation · Bacteria · Grazing

Resale or republication not permitted without written consent of the publisher

\section{INTRODUCTION}

To better understand ciliate ecology in hyporheic zones, advanced quantities such as growth rate, production, feeding and grazing loss must be taken into consideration in addition to the more basic diversity parameters. Furthermore, as the ciliate community within hyporheic zones is dominated by primarily bacterivores, it is especially important to obtain insights into the role of bacterivory in ciliate ecology for this type of aquatic habitat. Thus, in our study, ciliate bacterivory was investigated with regard to its importance as a carbon source for ciliate growth.
There are 2 forms of estimates of ciliate growth: indirect and direct. Indirect methods include (1) the extrapolation of laboratory-derived growth rates to natural populations, (2) the use of laboratory-derived growth-cell volume/temperature relationships, and (3) the measurement of the frequency of dividing cells (e.g. Fenchel 1968, Finlay 1977, Montagnes et al. 1988, Leakey et al. 1994, Montagnes 1996 and references therein). However, environmental variability is difficult to simulate in vitro, and thus laboratory conditions seldom reflect natural conditions (e.g. Leakey et al. 1994, Laybourn-Parry et al. 2000). In contrast, in situ incubation studies minimize many of the shortcomings 
of laboratory conditions, allowing direct observation of changes in natural population numbers. However, the resulting growth rates may be underestimates (e.g. due to predator-induced mortality).

We thus decided to use a direct estimate of ciliate growth and chose the dilution technique of Landry \& Hassett (1982). This technique is applicable in situ and provides a growth rate not influenced by predation. We modified this dilution technique (originally developed for plankton studies) for use in the interstitial habitat. The study was conducted in October to November 2002, as the highest number of ciliates (necessary for the success of a growth study) is found at this time of year (Cleven 2004a).

The aim of the present study was to estimate growth rates of interstitial ciliates and to combine these results with taxon-specific bacteria ingestion rates. To estimate the latter we chose FISH to detect ingested bacteria within food vacuoles of interstitial ciliates (Diederichs et al. 2003) and referred to observations and findings of classical feeding experiments. Consecutively, it should then be possible to assess the role of bacterivory as a carbon source for interstitial ciliate growth in the field and at this time of year. Furthermore, estimates of ciliate production and grazing loss will enable a better understanding of hyporheic ciliate ecology.

\section{MATERIALS AND METHODS}

Study site. The study was conducted in the sandy hyporheic zone of the upper reach of the Ladberger Mühlenbach, a second-order stream in the Teutoburger Forest area in the northwestern lowlands of Germany. Details on general and specific characteristics of this hyporheic zone are given in Cleven \& Meyer (2003).

Field sampling. The investigation was conducted on 3 days (Days 0, 21 and 35) in October to November 2002, as a previous study at the same site had shown highest hyporheic ciliate abundance at this time (Cleven 2004a). The investigation area was an $845 \mathrm{~m}$ long section of the Ladberger Mühlenbach divided into 169 patches of $20 \mathrm{~m}^{2}$ each. From these, 1 patch was selected randomly. Sediment cores $(\mathrm{n}=4 ; 56 \mathrm{~mm}$ in diameter) of the upper $3 \mathrm{~cm}$ were taken using the clay stopper sealing technique (Cleven 1999). Subsamples of the upper $3 \mathrm{~cm}$ were taken for determination of bacteria and ciliate abundance using small subcorers (9 and $16 \mathrm{~mm}$ inner diameter, respectively), fixed in $50 \mathrm{ml}$ plastic tubes containing $10 \mathrm{ml}$ of ice-cold glutaraldehyde ( $2 \%$ final conc.) and stored on ice until cell extraction. Further sediment subsamples were fixed with ice-cold glutaraldehyde ( $2 \%$ final conc.) for enumeration of heterotrophic flagellates.
Streambed temperatures were measured with a conventional mercury thermometer inserted into the sediment $\left(0\right.$ to $3 \mathrm{~cm}$ ); these were $10.3,8.8$ and $8.0^{\circ} \mathrm{C}$ on the 3 respective sampling dates. Sediment dry weight (DW) was determined after drying to constant weight at $105^{\circ} \mathrm{C}$

Bacterial abundance. Quantitative extraction of the bacteria from the sediment using a Bandelin Sonopuls HD 2070 sonifier (Bandelin) followed the protocol of Epstein \& Rossel (1995). A washing procedure followed by supernatant collection was repeated at least 5 times per sample (E.-J. Cleven unpubl.). An aliquot was stained with 4,6-diamidino-2-phenylindole (DAPI, $5 \mu \mathrm{g} \mathrm{ml}^{-1}$ final conc., Sigma-Aldrich) according to the protocol of Schallenberg et al. (1989) to enumerate bacteria by epifluorescence microscopy (Zeiss Axioskop; UV-excitation-filter-set [BP365, FT395, LP397]).

Abundance of heterotrophic nanoflagellates. Nanoflagellates were extracted by gentle mixing and washing, stained with $5 \mu \mathrm{g} \mathrm{ml}^{-1}$ DAPI according to the protocol of Schallenberg et al. (1989) and enumerated by epifluorescence microscopy (more detailed information is given in Cleven 1999 and Cleven \& Weisse 2001).

Determination of ciliates. The same ciliate taxa were present in both the benthic and hyporheic zone (Cleven 2004a); thus, hereafter we use the terms ciliates, benthic ciliates and interstitial ciliates synonymously.

Quantitative extraction and purification were performed by washing the sample and collecting the supernatants. After a settling time of $48 \mathrm{~h}$, the new supernatant was pipetted off with the exception of a few milliliters extract. To separate cells from detritus, a subsample of $2 \mathrm{ml}$ of the extract was purified by isopycnic centrifugation using Percoll following the protocol of Cleven (2004a).

For microscopical examination, the ciliates were stained with protargol silver (Merck) according to Skibbe (1994) to enable enumeration and taxonomical identification of the cells (quantitative protargol staining, QPS). Staining protocol, enumeration and identification followed the descriptions given in Cleven (2004a). The cell biomass of identified species was estimated according to Foissner et al. (1995), assuming that $1 \mathrm{pg}$ fresh weight equals $1 \mathrm{\mu m}^{3}$ biovolume (Finlay 1982). Ciliate carbon content per unit volume was cal-

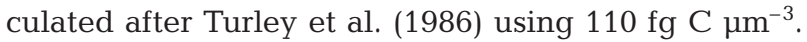
The lengths and widths of unidentifiable cells were measured using an ocular grid, and cell volumes were calculated by approximation of simple geometric shapes assuming an average conversion factor of 4 (ratio live volume:fixed volume; Pfister et al. 1999). The carbon content per unit volume of these cells was calculated according to Turley et al. (1986) as stated above. 
Determination of bacteria ingestion by interstitial ciliates. In contrast to classical tracer experiments in which a time zero is defined, e.g. by the addition of labelled prey to the predators, FISH does not allow time zero definition. Consequently, no time period was initiated and no rate could be calculated.

However, with a set of conditions and information it was possible to convert the food vacuole content of ciliates determined by FISH into bacteria ingestion rate: (1) the occurrence of an equilibrium between ingestion and digestion according to Sherr et al. (1988); (2) the numerical value at the $y$-intercept of this equilibrium; and (3) digestion time. For example, if digestion time is $1 \mathrm{~h}$ (i.e. equilibrium is reached after $1 \mathrm{~h}$ ), digestion and ingestion rates can be directly read as the numerical value at the $y$-intercept $\left(x y\right.$ cells $\left.\mathrm{h}^{-1}\right)$; for a digestion time of $20 \mathrm{~min}$, this numerical value would be tripled, for a digestion time of $2 \mathrm{~h}$ it would be halved.

Six sediment samples were taken at 30 min intervals over a period of $2.5 \mathrm{~h}$ to determine the exact time of equilibrium and, in combination, the numerical value at the $y$-intercept. The samples were fixed with paraformaldehyde ( $4 \%$ final conc.). The digestion time of $1 \mathrm{~h}$ was taken from the literature, where reported digestion times range between 20 and 120 min (Elliot \& Clemmons 1966, Sherr et al. 1988, Gunderson \& Goss 1997). The combination of FISH and QPS then allowed taxon-specific estimation of ingestion of bacteria.

For this purpose, extracted ciliates were treated following the protocol of Fried et al. (2002), who combined the FISH with QPS as modified by Skibbe (1994). Processing followed the QPS protocol up to the dehydration step in $90 \%$ alcohol inclusive. Whole-cell hybridisation was then carried out following the protocol of Diederichs et al. (2003) using sulfoindocyanine (Cy3)-labelled oligonucleotide probes specific for eubacteria (EUB338, EUB338-II, EUB338-III, Thermo Hybaid). Subsequently, filters were counter-stained with DAPI ( $1 \mu \mathrm{g} \mathrm{ml}^{-1}$ final conc.) for easier location of the ciliates. After fluorescence microscopy of the FISHtreated slides, the mounting fluids were rinsed and the QPS then continued (Skibbe 1994). The filters were finally embedded in Canada balsam for permanent slides and investigated by light-microscopy for taxonspecific identification.

In situ growth rates of interstitial ciliates. Background: We used the dilution technique of Landry \& Hassett (1982) to determine the in situ gross growth of the ciliates. Originally this technique was used in plankton studies. It reduces the probability of predator/prey encounters via a series of seawater dilutions, thus enabling the prey to display its inherent growth potential. Growth rates and also grazing mortality can be inferred from observed changes in prey density over time.
The dilution technique entails the following assumptions (Landry \& Hassett 1982, Tremaine \& Mills 1987): (1) a decrease in cell number will not directly result in a change in the growth rate of the cells remaining; (2) the probability of a prey cell being consumed is a direct function of the rate of encounter of consumers with prey cells (this implies that consumers are not food-satiated at natural prey densities and that the number of prey ingested by a given consumer is linearly related to prey density); and (3) the change in the density of prey over time is appropriately represented by the exponential equation $N_{t}=N_{0} \mathrm{e}^{\mu t}$, with $\mu=k-g$, where $\mu$ is the net specific growth rate, $N$ is cell abundance $\mathrm{g}^{-1}$ sediment DW, $t$ is duration of the experiment (d), and $k$ and $g$ are instantaneous coefficients of population growth and mortality. Through dilution, $g$ decreases towards zero and $k$ approximates $\mu$. The microorganismic growth (net specific growth) in each dilution is expected to be linearly related to the dilution factor. When calculating a linear regression the $y$ axis intercept is the prey growth rate $\mu_{\mathrm{G}}$ (at a theoretically very high dilution). As an additional quantity, the negative slope of the relationship rate of change of prey density at the different dilutions:dilution factor provides a grazing coefficient $b$ (mortality loss of ciliates through predation).

The dilution technique was modified for use in the interstitial habitat: a dilution series of original untreated and of preconditioned ('prefiltered' in Landry \& Hassett 1982) sediment from the Ladberger Mühlenbach was established.

Preconditioning of sediment: Of the upper $3 \mathrm{~cm}$ sediment from the Ladberger Mühlenbach, 10 l were transported to the laboratory and autoclaved in portions. The sediment was then placed in a flume and flooded by 121 prefiltered (1.2-polycarbonate membrane filters, Millipore Isopore) pond and tap water (ratio 1:6 for easier filtration) to recolonize the sediment with bacteria and flagellates as potential ciliate food (prefiltration excluded contamination by ciliates). During the $8 \mathrm{wk}$ preconditioning period, contamination of ciliates was monitored by DAPI-staining and epifluorescence microscopy. Before using the preconditioned sediment for the dilutions, abundance of bacteria and heterotrophic flagellates was determined by DAPI staining and epifluorescence microscopy and compared to field abundances at the beginning of incubation $\left(t_{0}\right)$. The preconditioned and ciliate-free sediment was then used to dilute the original stream sediment to separate ciliates from their potential predators.

Experimental set-up: Perforated cylindrical polystyrene chambers (75 ml microcosms) were used for the field incubation. An inner gauze of $1 \mu \mathrm{m}$ mesh size was glued over the perforations to prevent immigra- 
tion of ciliates and potential predators (e.g. metazoan meiofauna) and emigration of the enclosed ciliates. The chambers were then wrapped in a $20 \mu \mathrm{m}$ gauze to prevent damage to the inner gauze. In 4 parallel dilution series, the chambers were filled with sediment preconditioned in the flume and original untreated field sediment (upper $3 \mathrm{~cm}$ ) in the ratios 1:0 $(100 \%$ original sediment), $1: 1(50 \%), 1: 2(33.3 \%)$, and $1: 3$ $(25 \%)$. The sediment dilutions were gently mixed. An extensively perforated box served as a container for all chambers and was buried in the upper layer of the streambed. As our study is the first to determine growth of interstitial ciliates in the field we could not refer to any literature to establish an incubation time. We decided on an incubation period of $35 \mathrm{~d}$ with 3 sampling days (Days 0, 21, and 35) in October to November 2002. All chambers were sampled on 22 October $\left(t_{0}\right), 12$ November $\left(t_{1}\right)$, and on 26 November $\left(t_{2}\right)$ using a subcorer (16 mm inner diameter).

Calculations: Assuming exponential growth, taxonspecific growth rates were calculated from changes in abundance according to:

$$
\mu=\ln \left(N_{t} / N_{0}\right) / t
$$

The $y$-axis intercept of the linear regression is $\mu_{\mathrm{G}}$ $\left(\mathrm{d}^{-1}\right)_{\text {; }}$ the negative slope provides the grazing coefficient $b\left(\mathrm{~d}^{-1}\right)$.

Based on the mean ciliate standing crop at $t_{0}$ and the estimated growth rate $\mu_{\mathrm{G}}$, carbon requirement was calculated, and a gross growth efficiency of $25 \%$ (Straile 1997) was used to determine the required bacterial carbon ingestion. For this determination we used bacteria ingestion rates estimated by the FISH technique as well as taxon-specific ciliate carbon biomasses calculated according to Finlay (1982), Turley et al. (1986) and Foissner et al. (1995). The carbon ingestion required was transformed into individual theoretical bacteria uptake by converting the bacterial carbon biomass into bacteria cell number according to Austin \& Findlay (1989), who proposed $2 \times 10^{-14}$ $\mathrm{g} \mathrm{C}$ cell $^{-1}$.

Estimated ciliate growth and mortality were used to compute ciliate carbon production (CCP) and predatory loss (CPL) according to the equations of Landry et al. (2000, and references therein):

$$
\begin{aligned}
\mathrm{CCP} & =\mu_{\mathrm{G}} \times \mathrm{CB} \\
\mathrm{CPL} & =b \times \mathrm{CB}
\end{aligned}
$$

and

$$
\mathrm{CB}=\mathrm{CB}_{\text {ini }}\left[\mathrm{e}^{\left(\mu_{\mathrm{G}}-b\right) t}-1\right] /\left(\mu_{\mathrm{G}}-b\right) t
$$

where $\mathrm{CB}$ is the geometric mean ciliate carbon biomass and $\mathrm{CB}_{\text {ini }}$ is the initial ciliate carbon biomass. Ciliate carbon productions were calculated for the lateautumn investigation periods of $21 \mathrm{~d}$ (all taxa and groups except Placus spp.) and $35 \mathrm{~d}$ (Placus spp.).
Data analyses. Statistic analysis was carried out using SPSS software (Version 10.0, SPSS). One-way ANOVAs were used to test for differences between samples in bacteria ingestion over the period of $2.5 \mathrm{~h}$ and for differences between different sampling dates. Student's $t$-tests were conducted to test differences between bacteria and flagellate abundance in the flume, the field and the microcosms. Bonferroni posthoc tests were performed for the subsequent multiple comparisons. The raw data were $\log$ - or $\log (x+1)$ transformed to achieve normal distribution and homoscedasticity. To ensure an ordinate intercept statistically significantly different from zero, regression coefficients were compared with the slope of the abscissa following Sachs (1984) and Kreyszig (1988). The statistical significance level was set at $\alpha=0.05$.

\section{RESULTS}

\section{Bacteria and flagellates}

Mean bacteria abundance in the preconditioned sediment in the flume was statistically significantly different from field abundance in the October field sample ( $p=0.000$, one-way ANOVA) (Fig. 1), but not from field abundance in the November samples $(p=1.000$, oneway-ANOVA). Samples randomly taken from the microcosms (to track bacterial abundance during incubation) yielded mean bacterial cell numbers similar in magnitude to the field abundances in November (Fig. 1).

Mean heterotrophic flagellate abundance in the flume sediment was not statistically significantly different from mean field abundance at $t_{0}(\mathrm{p}=0.969$, Student's $t$-test) (Fig. 2). Flagellate cell numbers in field

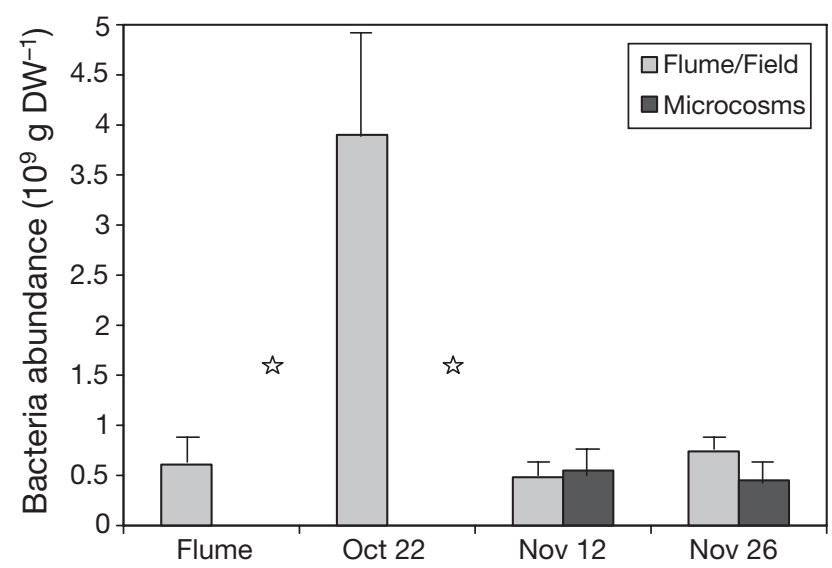

Fig. 1. Bacteria abundances (mean $+\mathrm{SD})$ in the flume (preparation of the preconditioned sediment), the field and in the microcosms (chambers for the field incubations) in October and November 2002. Stars denote significant differences between the October abundances and all other values $(\mathrm{p}<0.05)$ 


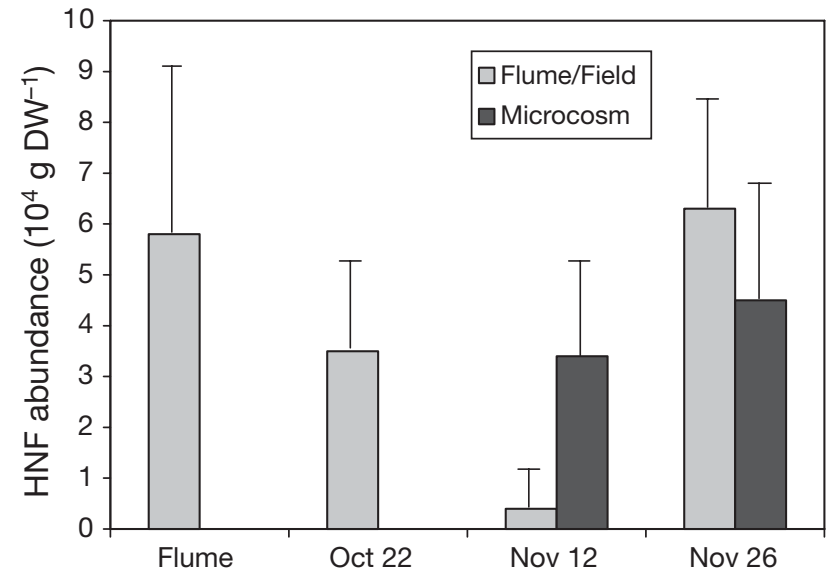

Fig. 2. Heterotrophic nanoflagellate (HNF) abundances (mean + SD) in the flume (preparation of the preconditioned sediment), the field and in the microcosms (chambers for the field incubations)

and microcosm controls yielded no significant differences in the November samples ( $p=0.110$, Student's $t$-test, and $\mathrm{p}=0.253$, Student's $t$-test, respectively). No ciliates were found in the preconditioned sediment.

\section{Ciliates}

The ciliate community was predominantly composed of hymenostome ciliates. The subclass Hymenostomatia was dominated by Cinetochilum margaritaceum, other small scuticociliates, and Pleuronema spp. Their contributions to the total community abundance of 128 , 58 and 90 cells $\mathrm{g}^{-1}$ sediment DW (22 October and 12 and 26 November, respectively) ranged between 4 and 21 cells (C. margaritaceum), 15 and 55 cells (other small scuticociliates), and 2 and 30 cells (Pleuronema spp.) $\mathrm{g}^{-1}$ sediment DW, respectively. Other dominant taxa colonizing the sediment belonged to the subclasses Peritrichia (e.g. Cothurnia annulata, Pyxicola carteri, Vorticella spp.), Hypotrichia (e.g. Aspidisca spp., Euplotes spp., Holosticha spp.), and Prostomatia (Placus spp.). Some ciliates for which determined abundances were low belonged to the Heterotrichia, Nassophoria and Gymnostomatia.

\section{Evaluation of bacteria ingestion rates by FISH}

FISH signals were received from (and thus bacteria were present in the food vacuoles of) Cinetochilum margaritaceum, other small scuticociliates, Pleuronema spp., and Vorticella spp. (E.-J. Cleven unpubl.). For all 4 taxa a levelling off (i.e. attainment of equilibrium between ingestion and digestion at a certain food vacuole content) could be assumed. Thus, at a chosen digestion time of $1 \mathrm{~h}$, the food vacuole content could then be taken for taxon-specific individual ingestion rate estimations. C. margaritaceum cells contained 26 bacteria ind..$^{-1}$ on average in their food vacuoles, corresponding to an ingestion rate of 26 bacteria ind..$^{-1} \mathrm{~h}^{-1}$. The overall mean bacteria ingestion rates for the other small scuticociliates, Pleuronema spp. and the Vorticella spp. were 50, 86 and 38 bacteria ind. ${ }^{-1} \mathrm{~h}^{-1}$, respectively. Estimation of ingestion rate was restricted to these 4 taxa; other taxa were present in very low cell numbers or were not present at all (E.-J. Cleven unpubl.).

\section{Determination of gross growth rates}

Analysis of the growth experiments and the subsequent regressions yielded parameters for representatives of the Hymenostomatia, Prostomatia, Hypotrichia, Peritrichia and Phyllopharyngia. However, statistically significant $\mu_{\mathrm{G}}$ could only be obtained for a few of these taxa: the Hymenostomatia, the hymenostome representatives Cinetochilum margaritaceum, other small scuticociliates, Pleuronema spp., and for the prostomatid ciliates Placus spp. (Table 1, Fig. 3). The slopes of the regression lines were significantly different $(p<0.05)$ from that of the abscissa (zero by definition). For the first 3 taxa listed above this was true for both the $21 \mathrm{~d}$ and the $35 \mathrm{~d}$ period (Table 1). Exceptions were Pleuronema spp., whose regression slope was significant for $t_{0}$ to $t_{1}$ only, and Placus spp., for which a significant slope was determined only for $t_{0}$ to $t_{2}$ (Table 1). Slopes of regressions that were not statistically significantly different from zero were not considered further.

Over the $21 \mathrm{~d}$ period, $\mu_{\mathrm{G}}$ varied from $0.070 \mathrm{~d}^{-1}(95 \%$ CI: $\left.\pm 0.055 \mathrm{~d}^{-1}\right)$ for Pleuronema spp. to $0.089 \mathrm{~d}^{-1}(95 \%$ CI: $\pm 0.042 \mathrm{~d}^{-1}$ ) for other small scuticociliates (Table 1, Fig. 3). Due to the dominance of Cinetochilum margaritaceum and the other small scuticociliates the growth coefficient for the total Hymenostomatia was strongly influenced by the $\mu_{\mathrm{G}}$ of these taxa (Table 1). $\mu_{\mathrm{G}}$ estimated over the $35 \mathrm{~d}$ period ( $t_{0}$ to $t_{2}$ ) ranged from 0.093 $\mathrm{d}^{-1}$ (95\% CI: $\pm 0.039 \mathrm{~d}^{-1}$; Hymenostomatia) to $0.145 \mathrm{~d}^{-1}$ (95\% CI: $\pm 0.045 \mathrm{~d}^{-1}$; Placus spp.) (Table 1). Statistical comparisons of the regression coefficients of $t_{0}$ to $t_{1}$ and $t_{0}$ to $t_{2}$ revealed no differences between the regressions $(\mathrm{p}<0.05)$. Calculated mean generation times varied from $4.8 \mathrm{~d}$ for Placus spp. to $9.9 \mathrm{~d}$ for Pleuronema spp. (Table 2).

\section{Ciliate carbon productions and predatory losses}

Ciliate carbon production was calculated for the lateautumn investigation periods of $21 \mathrm{~d}$ (all taxa and 
Table 1. Synthesis of parameters of the linear regressions obtained from the dilution experiments. $t_{0}$ to $t_{1}=$ first incubation period $(21 \mathrm{~d})$ and $t_{0}$ to $t_{2}=$ prolonged incubation period $(35 \mathrm{~d})\left(t_{0}: 22\right.$ October $2002 ; t_{1}: 12$ November 2002; $t_{2}: 26$ November 2002); $\mu_{\mathrm{G}}=$ gross growth coefficient $\left(\mathrm{d}^{-1}\right)(95 \%$ CI in parentheses $) ; b=$ predation coefficient $\left(\mathrm{d}^{-1}\right.$; slope of the linear regression) with $95 \%$ CI (in parentheses); $\mathrm{r}^{2}=$ squared correlation coefficient. Only significant slopes are listed $(\alpha=0.05)$

\begin{tabular}{|lccc|}
\hline Taxon & \multicolumn{1}{c|}{$\mu_{\mathrm{G}}$} & $b$ & $\mathrm{r}^{2}$ \\
\hline $\boldsymbol{t}_{\mathbf{0}}$ to $\boldsymbol{t}_{\mathbf{1}}$ & & & \\
Hymenostomatia & $0.082(0.043$ to 0.121$)$ & $-0.143(-0.208$ to -0.078$)$ & 0.612 \\
Cinetochilum margaritaceum & $0.084(0.040$ to 0.127$)$ & $-0.148(-0.226$ to -0.070$)$ & 0.564 \\
Other small scuticociliates & $0.089(0.047$ to 0.132$)$ & $-0.133(-0.204$ to -0.061$)$ & 0.528 \\
Pleuronema spp. & $0.070(0.015$ to 0.125$)$ & $-0.175(-0.269$ to -0.081$)$ & 0.634 \\
$\boldsymbol{t}_{\mathbf{0}}$ to $\boldsymbol{t}_{\mathbf{2}}$ & $0.093(0.054$ to 0.132$)$ & $-0.158(-0.224$ to -0.092$)$ & 0.656 \\
Hymenostomatia & $0.098(0.040$ to 0.157$)$ & $-0.149(-0.247$ to -0.051$)$ & 0.430 \\
Cinetochilum margaritaceum & $0.114(0.061$ to 0.167$)$ & $-0.188(-0.277$ to -0.099$)$ & 0.596 \\
Other small scuticociliates & $0.145(0.100$ to 0.190$)$ & $-0.168(-0.250$ to -0.087$)$ & 0.707 \\
Placus spp. & & & \\
\hline
\end{tabular}
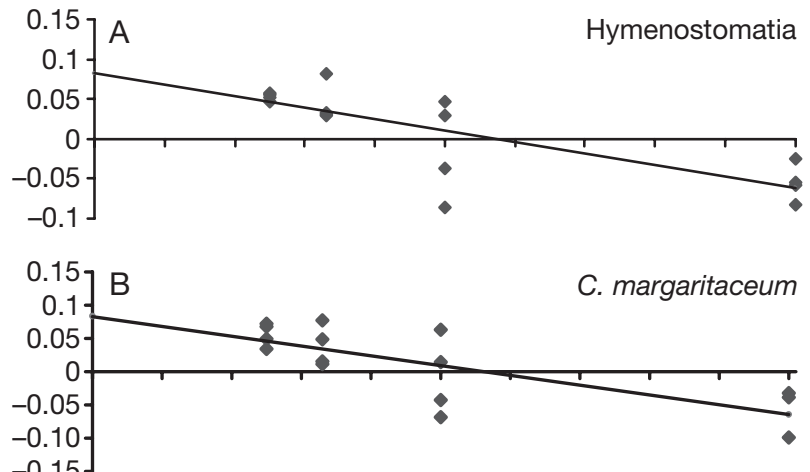

$-0.15]$
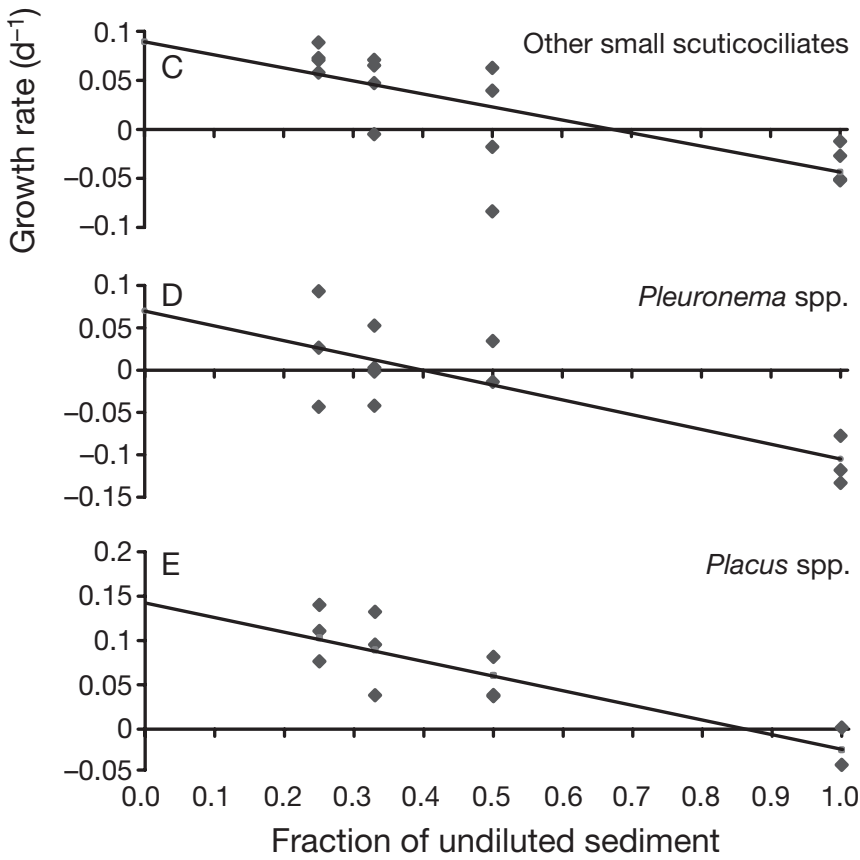

Fig. 3. Regression analysis of the dilution experiments. Derivations of the growth coefficients based on the incubation periods of (A-D) $21 \mathrm{~d}$ and (E) $35 \mathrm{~d}$ for the Hymenostomatia, Cinetochilum margaritaceum, other small scuticociliates, Pleuronema spp., and Placus spp. groups except Placus spp.) and $35 \mathrm{~d}$ (Placus spp.) based on the $\mu_{\mathrm{G}}$ in Table 1 as well as on taxon-specific conversions into carbon biomass (Table 2). Mean carbon production for all taxa and groups (with the exception of Placus spp.) ranged between $7 \mathrm{ng} \mathrm{C} \mathrm{g}^{-1}$ sediment DW per investigation period (corresponding to a mean carbon production of $0.4 \mathrm{ng} \mathrm{C}^{-1}$ sediment DW $\mathrm{d}^{-1}$; Cinetochilum margaritaceum), and $226 \mathrm{ng} \mathrm{C} \mathrm{g}^{-1}$ sediment DW per investigation period (corresponding to a mean carbon production of $11.3 \mathrm{ng} \mathrm{C} \mathrm{g}^{-1}$ sediment DW $\mathrm{d}^{-1}$; Hymenostomatia). Mean carbon production for Placus spp. was $6 \mathrm{ng} \mathrm{C} \mathrm{g}^{-1}$ sediment DW per investigation period or $0.2 \mathrm{ng} \mathrm{C} \mathrm{g}^{-1}$ sediment $\mathrm{DW} \mathrm{d} \mathrm{d}^{-1}$. When the $95 \%$ CI were taken into consideration, this yielded wide ranges (Table 2).

Mean predatory losses of the standing crop of interstitial ciliate carbon biomass (Table 3) ranged from $13.3 \% \mathrm{~d}^{-1}$ (other small scuticociliates) to $17.9 \% \mathrm{~d}^{-1}$ (Placus spp.); mean predatory losses of the carbon production of interstitial ciliates were in the range $114.9 \%$ $\mathrm{d}^{-1}$ (Placus spp.) to $250.1 \% \mathrm{~d}^{-1}$ (Pleuronema spp.). Here also, when upper and lower confidence limits were taken into consideration this yielded wider ranges (Table 3).

\section{Ciliate carbon requirement for growth and role of bacterivory}

The carbon requirement for growth and the bacteria carbon ingestion required for this growth was calculated based on ciliate biomasses and bacteria ingestions (see earlier subsection 'Evaluation of bacteria ingestion rates by $\mathrm{FISH}^{\prime}$ ) as well as on the $\mu_{\mathrm{G}}$ presented above (see earlier subsection 'Determination of gross growth rates'; Table 4). For example, taking the carbon biomass of Cinetochilum margaritaceum at a $t_{0}$ of $7.4 \mathrm{ng} \mathrm{C} \mathrm{g}^{-1}$ sediment DW) and the corresponding 
Table 2. Mean generation times (d) (values in parentheses based on 95\% CI of $\mu_{\mathrm{G}}$ in Table 1) and mean ciliate carbon production $\left(\mathrm{CCP} ; \mathrm{ng} \mathrm{C} \mathrm{g}^{-1} \mathrm{DW}\right.$ per investigation period) (maximum ranges, based on the $95 \% \mathrm{CI}$ of the growth and predation coefficients in Table 1, are given in parentheses). Generation times and CCP based on the $21 \mathrm{~d}$ (all taxa and groups except for Placus spp.) and $35 \mathrm{~d}$ investigation period (Placus spp.)

\begin{tabular}{|lcc|}
\hline Taxon & Generation time & CCP \\
\hline Hymenostomatia & $8.4(5.7$ to 16.1$)$ & $226(51$ to 916$)$ \\
Cinetochilum margaritaceum & $8.2(5.4$ to 17.3$)$ & $7(2$ to 38$)$ \\
Other small scuticociliates & $7.8(5.2$ to 14.7$)$ & $34(9$ to 175$)$ \\
Pleuronema spp. & $9.9(5.5$ to 46.2$)$ & $115(12$ to 788$)$ \\
Placus spp. & $4.8(3.6$ to 6.9$)$ & $6(1$ to 114$)$ \\
\hline
\end{tabular}

Table 3. Mean predatory losses $\left(\% \mathrm{~d}^{-1}\right)$ of carbon biomass standing crop and carbon production for interstitial ciliates. Maximum ranges, based on the $95 \% \mathrm{CI}$ of the growth and predation coefficients in Table 1, are given in parentheses. Predatory losses were estimated for $21 \mathrm{~d}$ (all taxa and groups except for Placus spp.) and $35 \mathrm{~d}$ (Placus spp.)

\begin{tabular}{|lcc|}
\hline Taxon & Biomass standing crop & Carbon product \\
\hline Hymenostomatia & $14.3(7.8$ to 20.8$)$ & $174.4(64.4$ to 483.7$)$ \\
Cinetochilum margaritaceum & $14.7(6.9$ to 22.6$)$ & $176.7(54.6$ to 565.8$)$ \\
Other small scuticociliates & $13.3(6.1$ to 20.4$)$ & $149.4(46.4$ to 435.4$)$ \\
Pleuronema spp. & $17.5(8.1$ to 26.9$)$ & $250.1(64.8$ to 1790.6$)$ \\
Placus spp. & $17.9(10.1$ to 24.4$)$ & $114.9(48.0$ to 232.5$)$ \\
\hline
\end{tabular}

Table 4. Ciliate carbon requirement $\mathrm{g}^{-1}$ sediment DW at $t_{0}(22$ October 02$)$. Mean standing crop $\left(\mathrm{ng} \mathrm{C} \mathrm{g}^{-1}\right.$ sediment $\left.\mathrm{DW}\right)=$ ciliate carbon biomass at $t_{0}$; $\mathrm{C}$ requirement (ng C g ${ }^{-1}$ sediment $\mathrm{DW} \mathrm{d} \mathrm{d}^{-1}$ ) = mean carbon requirement for growth (growth rates of $t_{0}$ to $t_{1}$ for all taxa and groups with the exception of Placus spp. [ $t_{0}$ to $\left.t_{2}\right]$ ); Req. $\mathrm{C}$ ingestion (ng C g ${ }^{-1}$ sediment $\mathrm{DW} \mathrm{d}^{-1}$ ) $=$ mean required carbon ingestion to enable growth assuming a gross growth efficiency of $25 \%$. Maximum ranges and $95 \%$ CI are not given for better clarity

\begin{tabular}{|lccc|}
\hline Taxon & $\begin{array}{c}\text { Mean } \\
\text { standing crop }\end{array}$ & $\begin{array}{c}\text { C } \\
\text { requirement }\end{array}$ & $\begin{array}{c}\text { Req. } \\
\text { C ingestion }\end{array}$ \\
\hline Hymenostomatia & 239.0 & 20.4 & 81.6 \\
Cinetochilum margaritaceum & 7.4 & 0.6 & 2.4 \\
Other small scuticociliates & 30.0 & 2.8 & 11.2 \\
Pleuronema spp. & 197.0 & 14.3 & 57.2 \\
Placus spp. & 1.6 & 0.2 & 0.8 \\
\hline
\end{tabular}

Table 5. Comparison of mean required carbon ingestion, converted into mean required theoretical bacteria uptake $\left(i n{ }^{-1} \mathrm{~d}^{-1}\right.$ ) required for individual carbon supply to enable growth, and mean real bacteria uptake $\left(i n{ }^{-1} \mathrm{~d}^{-1}\right.$ ) as determined by FISH for those taxa for which taxon-specific bacteria ingestion rates could be determined. S:R ratio (\%): carbon supply/carbon requirement ratio = mean contribution of bacterivory to carbon requirement for ciliate growth. Maximum ranges and $95 \% \mathrm{CI}$ are not given for better clarity

\begin{tabular}{|lccc|}
\hline \multirow{2}{*}{ Taxon } & \multicolumn{2}{c|}{ Bacterial uptake } & \\
& Theoretical & Real & S:R ratio \\
\hline Cinetochilum margaritaceum & 8889 & 624 & 7.0 \\
Other small scuticociliates & 10182 & 1200 & 11.8 \\
Pleuronema spp. & 95333 & 2064 & 2.2 \\
\hline
\end{tabular}

growth rate of $0.084 \mathrm{~d}^{-1}$ (Table 1), then this ciliate's carbon requirement for growth would be $0.6 \mathrm{ng} \mathrm{C} \mathrm{g}^{-1}$ sediment DW d $\mathrm{d}^{-1}$. Assuming a gross growth efficiency of $25 \%$, C. margaritaceum would have to take up $2.4 \mathrm{ng}$ $\mathrm{C} \mathrm{g}^{-1}$ sediment DW $\mathrm{d}^{-1}$ to satisfy this requirement and attain the growth determined. The mean carbon requirement of the other taxa (Table 4) varied between $0.8 \mathrm{ng} \mathrm{C}^{-1}$ sediment DW d ${ }^{-1}$ (Placus spp.) and $81.6 \mathrm{ng} \mathrm{C} \mathrm{g}^{-1}$ sediment DW d ${ }^{-1}$ (Hymenostomatia).

The carbon ingestion required was converted into a required theoretical individual bacteria uptake (Table 5) for Cinetochilum margaritaceum, for other small scuticociliates and for Pleuronema spp., for which taxon-specific bacteria ingestion rates had been estimated. The required theoretical mean bacteria ingestion was 8889 bacteria ind. ${ }^{-1} \mathrm{~d}^{-1}$ for C. margaritaceum, 10182 bacteria ind ${ }^{-1} \mathrm{~d}^{-1}$ for other small scuticociliates and 95333 bacteria ind. ${ }^{-1} \mathrm{~d}^{-1}$ for Pleuronema spp. (Table 5). A comparison of the theoretical ingestion rates with the actual bacterial uptakes evaluated by FISH (Table 5) revealed to what extent bacterivory covered the carbon requirement (supply:requirement [S:R] ratio; Table 5). For C. margaritaceum, mean bacterivory supplied $7.0 \%$ of the carbon required for the growth of this ciliate; for other small scuticociliates the S:R ratio amounted to $11.8 \%$, and for Pleuronema spp. to only $2.2 \%$.

\section{DISCUSSION}

\section{In situ ciliate growth rates and predatory losses}

\section{Growth rates}

The present study aimed at estimating in situ ciliate growth in association with ciliate bacterivory as a carbon source. To this end, we first had to calculate ciliate growth, which should be studied under field conditions. In order to imitate these conditions as closely as possible, grazing on the cili- 
ates by potential predators had to be eliminated and resource limitation during incubation avoided. Using the Landry \& Hassett (1982) technique, we reduced grazing pressure via a series of dilutions and obtained theoretically the greatest possible spatial separation of prey and predator by extrapolation of the dilution series to a zero fraction of original sediment. Resource limitation (food limitation; Landry \& Hassett 1982, Tremaine \& Mills 1987, Ayukai 1996) was avoided by enrichment of the preconditioned sediment with bacteria and heterotrophic nanoflagellates. In this way, determined growth coefficients (specific growth rates) equal or approximate maximum (intrinsic) growth rates. The growth coefficients are equivalent to gross growth rates as defined by Lampert \& Sommer (1993), assuming that grazing causes the most important population loss.

Until now, growth of ciliates has been nearly exclusively studied in the water column of freshwater or marine systems (e.g. Taylor 1978, Banse 1982, Müller \& Geller 1993, Macek et al. 1996, Laybourn-Parry et al. 2000). Growth was estimated via changes in abundance over time in laboratory investigations as well as in the field or, alternatively, by making calculations based on cell volume, temperature and maximum growth rate (e.g. Fenchel 1968, Finlay 1977, Montagnes et al. 1988, Müller \& Geller 1993, Macek et al. 1996, Montagnes 1996).

There is a lack of data on the growth rates of ciliates from hyporheic zones or other subsurface habitats. A reason for this is the exceptional difficulty in accessing this kind of study site (Hairston 1989, Palmer 1993), and laboratory experiments as an alternative to field studies suffer from the difficulty in stimulating complex in situ sediment conditions. Schönborn (1981, 1982) studied ciliate growth under approximate benthic/interstitial conditions. The rates of his first study are within the range we determined for our other small scuticociliates (Table 6). In Schönborn (1982), Paramecium spp. and Colpidium colpoda, which are comparable to Pleuronema spp., yielded equally comparable growth rates. Differences of up to 1 order of magnitude for one and the same species (Cinetochilum margaritaceum) or for representatives of nearly the same biovolume (small scuticociliates, Pleuronema spp.) may have their roots in different sampling periods. However, besides seasonal effects, the characteristics of the varying biotopes (e.g. hyporheic zone vs. pelagic zones of standing water bodies or laboratory conditions) and their environmental factors may influence ciliate growth. Such factors may be temperature, $\mathrm{pH}$, oxygen concentration, availability and nature of food, the ciliate's cell number per unit of volume and thus the intraand inter-specific competition for food and space. There are obviously large differences between condi- tions in the field and those in the laboratory. In the laboratory, studies were often conducted at temperatures close to the upper limits experienced in the natural environment, and on single-food species at excess levels (Laybourn-Parry et al. 2000). As such, they illustrate the potential for growth under ideal or nearly ideal conditions and are likely to be maximum estimates. In contrast, ideal conditions are never observed in the field (e.g. Fenchel 1968, Finlay 1977, Leakey et al. 1994, Laybourn-Parry et al. 2000). Nevertheless, exemplarily using the laboratory-based predictive equation of Montagnes et al. (1988) $-\ln \mu_{\mathrm{G}}=0.1438 T-$ $0.3285 \ln \left(V \times 10^{-3}\right)-1.3815$, where $\mu_{\mathrm{G}}$ is the maximum (intrinsic) growth rate $\left(\mathrm{d}^{-1}\right), T$ the ambient temperature (sediment temperature of $9^{\circ} \mathrm{C}$ used here; see 'Results') and $V$ the ciliate (live) volume in $\mu^{3}$ - calculations revealed growth rates of $0.54 \mathrm{~d}^{-1}$ for $C$. margaritaceum and $0.23 \mathrm{~d}^{-1}$ for Pleuronema spp., results which are within the range of previously published data (cf. Finlay 1977).

Considering all the restrictions concerning the difference between a planktonic and a hyporheic habitat, it is remarkable that the mean growth rates of small antarctic lake scuticociliates (determined at about $1^{\circ} \mathrm{C}$; Laybourn-Parry et al. 2000) differ from our mean rate for small scuticociliates (determined at about $9^{\circ} \mathrm{C}$ ) by a factor of up to 8, although ciliate growth is positively correlated with temperature (Fenchel 1968, Finlay 1977). Possible explanations for this contradiction may be found in the use of the microcosms.

\section{Methodology}

The use of microcosms (incubation chambers) may have caused artificial effects such as food (nutrient) and oxygen depletion ('containment effects' according to Leakey et al. 1994).

In the present study, containment effects caused by food depletion were minimized by the use of preconditioned sediment for dilution which had been recolonized with bacteria and flagellates as potential ciliate food. Bacterial abundance in that preconditioned sediment did not differ from in situ abundance during incubation; flagellate abundance in the preconditioned sediment was not different from that found in the field (Figs. 1 \& 2). Hence, we ruled out food depletion as a growth-limiting factor.

The perforated microcosms should ensure an exchange of interstitial water, and with it nutrients and oxygen. The sediment under study is well supplied with these resources (in nature), even decimetres below the sediment surface (Cleven 1999, Cleven \& Meyer 2003). However, the use of a $1 \mu \mathrm{m}$ gauze as a barrier may have restricted the desired permeability, 
Table 6. Growth rates of ciliates originating from freshwater cultures, freshwater planktonic and benthic/interstitial habitats and freshwater 'aufwuchs' as derived from changes in cell abundance, and from equations relating growth rate, cell size and temperature. For clarity, standard deviations, ranges and limits (95\% CI) are not listed. For $95 \%$ CI limits, see Table 1

\begin{tabular}{|c|c|c|c|}
\hline \multirow[t]{2}{*}{ Taxon } & \multicolumn{2}{|c|}{ Mean growth rates $\left(\mathrm{d}^{-1}\right)$} & \multirow[t]{2}{*}{ Source } \\
\hline & Change in abundance & Eq.- derived & \\
\hline Cyclidium glaucoma ${ }^{\mathrm{a}}$ & & 0.215 & Finlay (1977) \\
\hline Tetrahymena pyriformis & & 0.525 & Finlay (1977) \\
\hline Dexiostoma campylum ${ }^{\mathrm{a}}$ & & 0.337 & Finlay (1977) \\
\hline Paramecium aurelia $^{\mathrm{a}}$ & & 0.149 & Finlay (1977) \\
\hline Paramecium bursaria ${ }^{\mathrm{a}}$ & & 0.192 & Finlay (1977) \\
\hline Cinetochilum margaritaceum ${ }^{\mathrm{b}, \mathrm{j}}$ & 1.49 & & Taylor et al. (1978) \\
\hline Cinetochilum margaritaceum ${ }^{\mathrm{b}, \mathrm{h}}$ & 0.86 & $1.37-3.70$ & Macek et al. (1996) \\
\hline Cyclidium sp. ${ }^{\mathrm{b}, \mathrm{h}}$ & 0.80 & $1.98-5.35$ & Macek et al. (1996) \\
\hline Scuticociliates $^{\mathrm{b}, \mathrm{g}}$ & 0.49 & $1.11-1.69$ & Macek et al. (1996) \\
\hline Scuticociliates ${ }^{\mathrm{b}, \mathrm{i}}$ & $0.46-0.73$ & & Laybourn-Parry et al. (2000) \\
\hline Cinetochilum margaritaceum ${ }^{\mathrm{b}, \mathrm{f}}$ & $-0.17-0.51^{\mathrm{k}}$ & & Nakano et al. (2001) \\
\hline Cyclidium glaucoma ${ }^{\mathrm{b}, \mathrm{f}}$ & $0.85-1.10^{\mathrm{k}}$ & & Nakano et al. (2001) \\
\hline Cyclidium elongatum ${ }^{\mathrm{c}, \mathrm{e}}$ & $0.14-0.44$ & & Schönborn (1981) \\
\hline Colpidium colpoda ${ }^{\mathrm{c}, \mathrm{e}}$ & $0.07-0.35$ & & Schönborn (1982) \\
\hline Paramecium spp..$^{\mathrm{c}, \mathrm{e}}$ & $0.05-1.11$ & & Schönborn (1982) \\
\hline Hymenostomatia $^{\mathrm{d}}$ & 0.082 & & This study \\
\hline Cinetochilum margaritaceum ${ }^{\mathrm{d}}$ & 0.084 & & This study \\
\hline Other small scuticociliates $^{\mathrm{d}}$ & 0.089 & & This study \\
\hline Pleuronema spp. ${ }^{\mathrm{d}}$ & 0.070 & & This study \\
\hline \\
\hline \multirow{2}{*}{\multicolumn{4}{|c|}{ 'Pelagic origin }} \\
\hline & & & \\
\hline \multicolumn{4}{|c|}{${ }^{\mathrm{d} B e n t h i c / i n t e r s t i t i a l ~ o r i g i n ; ~ i n ~ s i t u ~ i n c u b a t i o n ~(O c t / N o v ~ f i e l d ~ t e m p .: ~} 8.0$ to $10.3^{\circ} \mathrm{C}$ ) } \\
\hline \multicolumn{4}{|c|}{ e In situ incubation (range of field temp.: ca. 1 to $17.5^{\circ} \mathrm{C}$ ) } \\
\hline \multicolumn{4}{|c|}{${ }^{\mathrm{f}}$ In situ incubation (Nov. field temp.: ca. $8^{\circ} \mathrm{C}$ ) } \\
\hline \multicolumn{4}{|c|}{${ }^{\mathrm{g}}$ In situ incubation (range of field temp.: $9.5-16.5^{\circ} \mathrm{C}$ ) } \\
\hline \multicolumn{4}{|c|}{${ }^{\mathrm{h}}$ Laboratory incubation at in situ temperature (range of field temp.: 14 to $22^{\circ} \mathrm{C}$ ) } \\
\hline \multicolumn{4}{|c|}{${ }^{\mathrm{i}}$ Laboratory incubation at in situ temperature (field temp.: $1^{\circ} \mathrm{C}$ ) } \\
\hline \multicolumn{4}{|c|}{${ }^{\mathrm{j}}$ Laboratory cultivation $\left(20^{\circ} \mathrm{C}\right)$} \\
\hline${ }^{\mathrm{k}}$ Dependent on the experimenta & $(<30 \mu \mathrm{m}$ fraction; total & & \\
\hline
\end{tabular}

especially because of the inevitable biofilm formation. Nevertheless, the 1 um barrier was essential for avoiding the immigration of ciliates and their potential predators and the emigration of the enclosed ciliates; an estimation of the ciliate growth under the exclusion of potential predators would have otherwise been impossible. Larger mesh sizes were shown to be insufficient, as demonstrated by our preliminary trials with a $5 \mu \mathrm{m}$ gauze. Leakey et al. (1994) also refer to the ability of ciliates with a mean cell diameter of up to $40 \mu \mathrm{m}$ to squeeze through a mesh size of $5 \mu \mathrm{m}$. With regard to this likely containment effect by biofilm formation we cannot completely neglect a possible limitation of the ciliate's growth.

For experiments performed in the pelagic zone, incubation times of $1 \mathrm{~d}$ are common. However, there are limited data on the growth rates of ciliates from hyporheic zones or subsurface aquatic habitats. The field studies of Schönborn $(1981,1982)$ yielded generation times of up to $15 \mathrm{~d}$ (cf. Table 2 of the present study). With regard to this, and in face of the disturbance when mixing (diluting) the natural sediment samples with the preconditioned sediment, we chose incubation times of 3 and $5 \mathrm{wk}$.

Slopes of regressions that were not statistically significantly different from the zero slope were excluded from further consideration. This was the case for Aspidisca spp. (Hypotrichia) and Cothurnia annulata and Pyxicola carteri (Peritrichia). Non-significant regression may be due to the fact that slight slopes are difficult to detect with regression analysis using the small ' $n$ ' values commonly employed (8 to 15; Dolan et al. 2000). In our study maximum 'n' was 16 .

\section{Predatory losses}

Predatory losses were calculated using the slope of the corresponding regressions (predation coefficients). This parameter quantifies a general predation loss of the ciliates and does not point to a certain predator or group of predators. Predatory losses may be caused by ciliates and representatives of the metazoan meiofauna (e.g. nematodes, tardigrades, rotifers; e.g. Giere 
1993, Rundle et al. 2002 and references therein). However, with respect to the dominating bacterivorous representatives of the ciliate community (E.-J. Cleven unpubl., see also Cleven 2004a), the effect of predatory ciliates can be assumed to be low.

All taxa (Fig. 3) showed negative growth rates in those microcosms filled exclusively with natural sediment $(100 \%$ original sediment). These results are interpreted to be the consequences of a predator's control, exceeding ciliate growth at that time of the year. These findings correspond to observations in the field where ciliate cell number decreased significantly (E.-J. Cleven unpubl.); they were also confirmed in a previous field study in which ciliate abundance in the near surface sediment layer was seen to decrease from the highest cell number at the end of November down to the low numbers of the winter (Cleven 2004a). The fact that all other studied microcosms (with 1:1, 1:2, and 1:3 diluted original sediment) incubated under the same environmental conditions showed positive growth rates confirms our interpretation of a predatory effect and demonstrates the successful application of the sediment dilution for estimating the growth coefficient.

\section{Importance of bacterivory for ciliate growth}

In light of the increasing evidence of discrimination against tracer particles (e.g. Landry et al. 1991, Boenigk et al. 2001, Cleven \& Weisse 2001, Cleven 2004b), we refrained from using a tracer technique and chose FISH to estimate ciliate bacterivory. Ciliates feed on their natural prey organisms, and after hybridisation of the probes to the bacterial rRNA, the Cy3signals only represent ingested bacteria. However, in comparison to literature (Sanders et al. 1989, Šimek et al. 1996) the ingestion rates of Cinetochilum margaritaceum ( 26 bacteria ind.$^{-1} \mathrm{~h}^{-1}$ ), other small scuticociliates (50 bacteria ind. ${ }^{-1} \mathrm{~h}^{-1}$ ) and Pleuronema spp. (86 bacteria ind..$^{-1} \mathrm{~h}^{-1}$ ) of the interstitial habitat under study were at the lower end.

Considering these ingestion rates, bacterivory supplied up to $12 \%$ of the ciliate's carbon requirements ( $\mathrm{S}: \mathrm{R}$ ratio mean value, Table 5) only. Even a consideration of the upper $95 \%$ CI limits would not provide outstanding results: $14.0 \%$ for C. margaritaceum, $23.6 \%$ for the other small scuticociliates and $10.3 \%$ for Pleuronema spp..

These carbon supplies are insufficient to maintain growth of the primarily bacterivorous ciliates under study. Therefore, 2 aspects should be considered to accommodate for this lack of carbon supply: (1) methodological aspects, and (2) alternative food sources.

\section{Methodological aspects}

One methodological aspect is the choice of digestion time. With regard to the range of digestion times given in the literature, even for representatives of the same taxon (Elliot \& Clemmons 1966, Gunderson \& Goss 1997), we opted for a digestion time of $1 \mathrm{~h}$ for these calculations. Recently, Jezbera et al. (2005) observed a digestion time of less than $30 \mathrm{~min}$ for the small scuticociliate Cyclidium glaucoma, probably a representative of our other small scuticociliates. Thus, it would also be justified to consider this digestion time and triple the ingestion (150 bacteria ind ${ }^{-1} \mathrm{~h}^{-1}$ for the other small scuticociliates, and 78 bacteria ind. ${ }^{-1} \mathrm{~h}^{-1}$ for the small scuticociliate Cinetochilum margaritaceum). The corresponding S:R ratios were 35.4 and $21.0 \%$, respectively.

A second methodological aspect is the limitations of FISH. Despite its positive features, the classic FISH technique suffers from some limitations which may have prevented the detection of a higher number of bacteria inside the ciliates' food vacuoles.

The percentage of DAPI stainable bacterial cells detected by the common EUB338 probe is not $100 \%$ per se, but varies from 1 to $100 \%$ in aquatic ecosystems (Bouvier \& del Giorgio 2003). Among different methodological and environmental variables tested by these authors, the fluorochrome used and the ecosystem type explained most of the mentioned variability. In respect to the fluorocromes, Cy3 gave the highest estimated mean of detection yield $(68 \%)$ and sediments gave an estimated mean of detection yield lower than $40 \%$. Thus, the detection yield of $59 \%$ determined earlier by Diederichs et al. (2003) in the sandy sediment of our study site using Cy3-labelled EUB338 probes was well within this range. For ciliate food vacuole content, an even higher detection yield can be expected (Diederichs et al. 2003).

A weak signal intensity attributable to insufficient cell permeability of the probe may prevent proof of a higher bacteria ingestion. The permeabilization problem is understood as the exclusion of the rRNAtargeted probe by the cell periphery, probably by the cell wall, since membranes are expected to be readily permeable after fixation. The use of paraformaldehyde ( $4 \%$ final conc.) is well known as a good fixative for most Gram-negative bacteria, but it may be detrimental for the permeabilization of cell-wall bearing Gram-positive bacteria (Amann et al. 1995). We do not know the bacteria community composition of the sediment under study with respect to Gram-positive and -negative cells, but assume that the Gram-negative representatives (e.g. Proteobacteria, nitrifying bacteria) dominate (Tamaki et al. 2005). Therefore we cannot exclude an underestimation of the bacteria ingestion by the ciliates. An enzymological pre-treat- 
ment would have alleviated this problem to some extent; however, cell permeability has to be carefully balanced against cell integrity to avoid cell loss (Zwirglmaier 2005).

A weak signal intensity may be due to a low ribosome content found in slowly growing or metabolically inactive cells. In contrast, growing or active cells tend to have more ribosomes, and hence bind more probe molecules, resulting in strong fluorescent signals detectable within ciliates' food vaculoes. Nevertheless, even cells with low activity or differences in cellular RNA content associated with changes in specific growth rate might have rRNA at a sufficient concentration to yield a fluorescent signal detectable with FISH (Oda et al. 2000, Bouvier \& del Giorgio 2003, and references therein). In this study, we detected generally strong fluorescence signals, which were taken as an indication for sufficient cellular rRNA content; therefore, no further signal amplification was applied (Zwirglmaier 2005).

Since the rRNA target molecules remain in the ribosomes of the whole fixed cells, probe hybridisation is influenced by RNA-RNA or RNA-protein interactions, which may result in in situ inaccessibility of the probe target site. However, in situ accessibility can be improved by addition of formamide to the hybridisation buffer (Amann et al. 1992). The hybridisation buffer used in our study contained $35 \%$ formamide, the most frequently employed concentration according to the reports listed by Bouvier \& del Giorgio (2003).

Signal detection of small-sized bacteria may be masked by background fluorescence of inorganic particles, detritus or other specimens (Amann et al. 1995, Bouvier \& del Giorgio 2003). However, hybridisation within the ciliates' food vacuoles took place in a much 'cleaner' environment than a hybridisation in the sand.

Another limitation may originate from the fact that rRNA diversity has only been partially described (Amann \& Ludwig 2000). Thus, there may be unknown microorganisms which are phylogenetically members of a probe target group, but do not contain a perfectly matching target site and were not detectable within the ciliates' food vacuoles.

Some of these aspects may explain the low ingestion rates presented above. However, in our study we used a standard FISH protocol that at least minimized most of these likely influences.

\section{Alternative food}

Ciliates need another source of carbon besides bacteria to achieve the growth rates that were measured in this study. Cinetochilum margaritaceum, other small scuticociliates and Pleuronema spp. are also known to feed on small diatoms, other small algae, flagellates and detritus (e.g. Foissner et al. 1994, Nakano et al. 2001). From microscopy (light and epifluorescence) we know of diatoms within the food vacuoles of Pleuronema spp. and can 'assume' ingestion of flagellates and small algae by smaller hymenostome ciliates. Another potential source of carbon may be a direct uptake of DOC, which was proven for some heterotrophic protists (e.g. Sherr 1988, Christoffersen et al. 1996). However, to what extent these possible carbon sources accommodate for the lack of carbon supply was beyond the scope of this study.

This field study focused on the ecology of single components of the microbial food web and elucidated details of the carbon transfer within a sandy hyporheic zone. The results reflect the carbon transfer over a short period of time only. This transfer may be completely different at other times of the year. Nevertheless, we were able to elucidate the trophic interaction between components of a microbial food web in a habitat which has thus far very rarely been investigated.

Acknowledgements. Thanks to S. Diederichs, A. Kirschner, and M. Prast for technical assistance and helpful comments. We also thank F. Bartlett, B. Cleven, P. Higgins, M. Landry, especially B. Spänhoff, and anonymous reviewers for comments on the manuscript and for correcting the English text.

\section{LITERATURE CITED}

Amann R, Ludwig W (2000) Ribosomal RNA-targeted nucleic acid probes for studies in microbial ecology. FEMS Microbiol Rev 24:555-565

Amann RI, Stromley J, Devereux R, Key R, Stahl DA (1992) Molecular and microscopic identification of sulfate-reducing bacteria in multispecies biofilms. Appl Environ Microbiol 58:614-623

Amann RI, Ludwig W, Schleifer KH (1995) Phylogenetic identification and in situ detection of individual microbial cells without cultivation. Microbiol Rev 59:143-169

Austin HK, Findlay SEG (1989) Benthic bacterial biomass and production in the Hudson River estuary. Microb Ecol 18: 105-116

Ayukai T (1996) Possible limitation of the dilution technique for estimating growth and grazing mortality rates of picoplanktonic cyanobacteria in oligotrophic tropical waters. J Exp Mar Biol Ecol 198:101-111

Banse K (1982) Cell volumes, maximal growth rates of unicellular algae and ciliates, and the role of ciliates in the marine pelagial. Limnol Oceanogr 27:1059-1071

Boenigk J, Arndt H, Cleven EJ (2001) The problematic nature of fluorescently labelled bacteria (FLB) in Spumella feeding experiments - an explanation by using video microscopy. Arch Hydrobiol 152:329-338

Bouvier T, del Giorgio PA (2003) Factors influencing the detection of bacterial cells using fluorescence in situ hybridization (FISH): a quantitative review of published reports. FEMS Microbiol Ecol 44:3-15

Christoffersen K, Bernard C, Ekebom J (1996) A comparison 
of the ability of different heterotrophic nanoflagellates to incorporate dissolved macromolecules. Arch Hydrobiol Spec Iss Adv Limnol 48:73-84

Cleven EJ (1999) An improved method of taking cores in sandy sediments. Arch Hydrobiol 147:65-72

Cleven EJ (2004a) Seasonal and spatial distribution of ciliates in the sandy hyporheic zone of a lowland stream. Eur J Protistol 40:71-84

Cleven EJ (2004b) Pelagic ciliates in a large mesotrophic lake: seasonal succession and taxon-specific bacterivory in Lake Constance. Int Rev Hydrobiol 89:289-304

Cleven EJ, Meyer EI (2003) A sandy hyporheic zone limited vertically by a solid boundary. Arch Hydrobiol 157: 267-288

Cleven EJ, Weisse T (2001) Seasonal succession and taxonspecific bacterial grazing rates of heterotrophic nanoflagellates in Lake Constance. Aquat Microb Ecol 23: 147-161

Diederichs S, Beardsley C, Cleven EJ (2003) Detection of ingested bacteria in benthic ciliates using fluorescence in situ hybridization. Syst Appl Microbiol 26:624-630

Dolan JR, Gallegos CL, Moigis A (2000) Dilution effects on microzooplankton in dilution grazing experiments. Mar Ecol Prog Ser 200:127-139

Elliot AM, Clemmons GL (1966) An ultrastructural study of ingestion and digestion in Tetrahymena pyriformis. J Protozool 13:311-323

Epstein SS, Rossel J (1995) Enumeration of sandy sediment bacteria: search for optimal protocol. Mar Ecol Prog Ser 117:289-298

Fenchel T (1968) The ecology of marine microbenthos. III. The reproductive potential of ciliates. Ophelia 5:123-136

Finlay BJ (1977) The dependence of reproductive rate on cell size and temperature in freshwater ciliated protozoa. Oecologia 30:75-81

Finlay BJ (1982) Effects on seasonal anoxia on the community of benthic ciliated protozoa in a productive lake. Arch Protistenkd 125:215-222

Foissner W, Berger H, Kohmann F (1994) Taxonomische und ökologische Revision der Ciliaten des Saprobiensystems. Band III. Hymenostomata, Prostomatida, Nassulida. Informationsberichte des Bayerischen Landesamtes für Wasserwirtschaft, Heft 1/94, München, p 1-548

Foissner W, Berger H, Kohmann F (1995) Taxonomische und ökologische Revision der Ciliaten des Saprobiensystems. Band IV. Gymnostomatea, Loxodes, Suctoria. Informationsberichte des Bayerischen Landesamtes für Wasserwirtschaft, Heft 1/95, München, p 1-540

Fried J, Ludwig W, Psenner R, Schleifer KH (2002) Improvement of ciliate identification and quantification: a new protocol for fluorescence in situ hybridization (FISH) in combination with silver stain techniques. Syst Appl Microbiol 25:555-571

Giere O (1993) Meiobenthology. The microscopic fauna in aquatic sediments, 1st edn. Springer, Berlin

Gunderson JH, Goss SH (1997) Fluorescently labelled oligonucleotide probes can be used to identify protistan food vacuole content. J Eukaryot Microbiol 44:300-304

Hairston NG (1989) Ecological experiments. Purpose, design, and execution, 1st edn. Cambridge University Press, Cambridge

Jezbera J, Horňák K, Šimek K (2005) Food selection by bacterivorous protists: insight from the analysis of the food vacuole content by means of fluorescence in situ hybridization. FEMS Microbiol Ecol 52:351-363

Kreyszig E (1988) Statistische Methoden und ihre Anwendungen, 7th edn. Vandenhoeck \& Ruprecht, Göttingen
Lampert W, Sommer U (1993) Limnoökologie, 1st edn. Thieme, Stuttgart

Landry MR, Hassett RP (1982) Estimating the grazing impact of marine micro-zooplankton. Mar Biol 67:283-288

Landry MR, Lehner-Fournier JM, Fagerness VL, Sundstrom JA, Selph KE (1991) Discrimination between living and heat-killed prey by a marine zooflagellate, Paraphysomonas vestita (Stokes). J Exp Mar Biol Ecol 146: 139-151

Landry MR, Constantinou J, Latasa M, Brown SL, Bidigare RR, Ondrusek ME (2000) Biological response to iron fertilization in the eastern equatorial Pacific (IronEx II). III. Dynamics of phytoplankton growth and microzooplankton grazing. Mar Ecol Prog Ser 2001:57-72

Laybourn-Parry J, Bell EM, Roberts EC (2000) Protozoan growth rates in anarctic lakes. Polar Biol 23:445-451

Leakey RJG, Burkill PH, Sleigh MA (1994) Ciliate growth rates from Plymouth sound: comparison of direct and indirect estimates. J Mar Biol Assoc UK 74:849-861

Macek M, Šimek K, Pernthaler J, Vyhnálek V, Psenner R (1996) Growth rates of dominant planktonic ciliates in two freshwater bodies of different trophic degree. J Plankton Res 18:463-481

Montagnes DJS (1996) Growth responses of planktonic ciliates in the genera Strobilidium and Strombidium. Mar Ecol Prog Ser 130:241-254

Montagnes DJS, Lynn DH, Roff JC, Taylot WD (1988) The annual cycle of heterotrophic planktonic ciliates in the waters surrounding the Isles of Shoals, Gulf of Maine. J Plankton Res 11:193-201

Müller H, Geller W (1993) Maximum growth rates of aquatic ciliated protozoa: the dependence on body size and temperature reconsidered. Arch Hydrobiol 126:315-327

Nakano S, Manage PM, Nishibe Y, Kawabata Z (2001) Trophic linkage among heterotrophic nanoflagellates, ciliates and metazoan zooplankton in a hypereutrophic pond. Aquat Microb Ecol 25:259-270

Oda Y, Slagman SJ, Meijer WG, Forney LJ, Gottschal JC (2000) Influence of growth rate and starvation on fluorescent in situ hybridization of Rhodopseudomonas palustris. FEMS Microbiol Ecol 32:205-213

Palmer MA (1993) Experimentation in the hyporheic zone: challenges and prospectus. J N Am Benthol Soc 12: 84-93

Pfister G, Sonntag B, Posch T (1999) Comparison of a direct live count and an improved quantitative protargol stain (QPS) in determining abundance and cell volumes of pelagic freshwater protozoa. Aquat Microb Ecol 18:95-103

Rundle SD, Robertson AL, Schmid-Araya JM (2002) Freshwater meiofauna: biology and ecology, 1st edn. Backhuys Publishers, Leiden

Sachs L (1984) Angewandte Statistik, 6th edn. Springer, Berlin

Sanders RW, Porter KG, Bennett SJ, DeBiase AE (1989) Seasonal patterns of bacterivory by flagellates, ciliates, rotifers, and cladocerans in a freshwater planktonic community. Limnol Oceanogr 34:673-687

Schallenberg M, Kalff J, Rasmussen JB (1989) Solutions to problems in enumerating sediment bacteria by direct counts. Appl Environ Microbiol 55:1214-1219

Schönborn W (1981) Die Ziliatenproduktion eines Baches. Limnologica 13:203-212

Schönborn W (1982) Die Ziliatenproduktion in der mittleren Saale. Limnologica 14:329-346

Sherr BF, Sherr EB, Rassoulzadegan F (1988) Rates of digestion of bacteria by marine phagotrophic protozoa: temperature dependence. Appl Environ Microbiol 54:1091-1095 
Sherr EB (1988) Direct use of high molecular weight polysaccharide by heterotrophic flagellates. Nature 335:348-351

Šimek K, Macek M, Pernthaler J, Straškrabová V, Psenner R (1996) Can freshwater planktonic ciliates survive on a diet of picoplankton? J Plankton Res 18:597-613

Skibbe O (1994) An improved quantitative protargol stain for ciliates and other planktonic protists. Arch Hydrobiol 130: 339-347

Straile D (1997) Gross growth efficiencies of protozoan and metazoan zooplankton and their dependence on food concentration, predator-prey weight ratio, and taxonomic group. Limnol Oceanogr 42:1375-1385

Tamaki H, Sekiguchi Y, Hanada S, Nakamura K, Nomura N, Matsumura M, Kamagata Y (2005) Comparative analysis of bacterial diversity in freshwater sediment of a shallow

Editorial responsibility: Karel Simek, Ceské Budejovice, Czech Republic eutrophic lake by molecular and improved cultivationbased techniques. Appl Environ Microbiol 71:2162-2169 Taylor WD (1978) Maximum growth rate, size and commonness in a community of bacterivorous ciliates. Oecologia $36: 263-272$

Tremaine SC, Mills AL (1987) Tests of the critical assumptions of the dilution method for estimating bacterivory by microeucaryotes. Appl Environ Microbiol 53:2914-2921

Turley CM, Newell RC, Robins DB (1986) Survival strategies of two small marine ciliates and their role in regulating bacterial community structure under experimental conditions. Mar Ecol Prog Ser 33:59-70

Zwirglmaier K (2005) Fluoresence in situ hybridization (FISH) - the next generation. FEMS Microbiol Lett 246: 151-158

Submitted: May 15, 2006; Accepted: November 29, 2006 Proofs received from author(s): April 23, 2007 